\title{
MODEL BISNIS PETERNAKAN KAMBING PERAH RAKYAT DI LINGKUNGAN PENYANDANG DISABILITAS (STUDI KASUS DESA KARANGPATIHAN)
}

\author{
Muhammad Syahrul Fuady ${ }^{1)}$; Joko Sumantri ${ }^{2)}$ \\ 1) syahrulfuady@pknstan.ac.id, Politeknik Keuangan Negara-STAN* \\ 2) jokosumantri@pknstan.ac.id, Politeknik Keuangan Negara-STAN \\ *email korespondensi
}

\begin{abstract}
This study purpose to create a canvas business model for goat farm in the context of empowering people with disabilities in Karangpatihan Village. The Business Model Canvas for dairy goat farming for the people of Karangpatihan Village is expected to be one of the efforts to increase the productivity of goat farming. By using qualitative research methods and the process of collecting data and information using the participatory rural appraisal (PRA) method, we found that the people of Karangpatihan Village were willing to raise dairy goats. In managing the dairy goat business, the people of Karangpatihan village experience obstacles in the form of natural conditions in the form of calcareous slopes, relatively little rainfall causing drought, and making it difficult for residents to get natural animal feed.
\end{abstract}

Keywords : disabilities, canvas business model, goats, empowering

\begin{abstract}
Abstrak
Penelitian ini bertujuan untuk membuat model bisnis kanvas beternak kambing perah dalam rangka pemberdayaan masyarakat di lingkungan penyandang disabilitas di Desa Karangpatihan. Model bisnis kanvas peternakan kambing perah di lingkungan masyarakat Desa Karangpatihan diharapkan dapat menjadi salah satu upaya meningkatkan pendapatan bagi peternak kambing perah non disabilitas maupun disabilitas . Dengan menggunakan metode penelitian kualitatif dan proses pengumpulan data dan infromasi menggunakan metode participatory rural appraisal (PRA), kami menemukan bahwa masyarakat Desa Karangpatihan berkeinginan melakukan ternak kambing perah yang nantinya bisa ditularkan untuk penyandang disabilitas. Dalam mengelola bisnis ternak kambing perah, masyarakat desa Karangpatihan mengalami kendala dalam penyimpanan dan pemasaran susu kambing, curah hujan yang relatif sedikit sehingga menyebabkan kekeringan, dan sulitnya warga mendapatkan pakan ternak natural di musim kemarau serta keterbatasan pengetahuan dalam menangani penyakit pada kambing. Kata Kunci : disabilitas, model bisnis kanvas, kambing, pemberdayaan
\end{abstract}

\section{PENDAHULUAN}

Berdasarkan data tahun 2017, Desa Karangpatihan-Kecamatan Balong, Ponorogo Jawa Timur pada tahun 2016 memiliki jumlah penduduk 5.746 jiwa atau $1.754 \mathrm{KK}$, yang terdiri dari 2.924 laki-laki dan 2.826 perempuan (BPS, 2018). Dari total penduduk di Desa Karangpatihan, pada tahun 2017, ada 98 warga penyandang keterbelakang mental yang terdistribusi di 4 dusun (Wulandari, et.al, 2021). Desa Karangpatihan kemudian menjadi terkenal dengan julukan "Kampung Idiot" karena banyak penduduknya mengalami tuna grahita atau keterbelakangan mental (Triono, 2018; Dewi, 2016; Aprianto, et. Al, 2019).

Di Desa Karangpatihan, rata-rata penduduk berprofesi sebagai buruh tani, memiliki tingkat pendidikan yang rendah, dan perolehan penghasilan yang relatif sedikit. Penghasilan mereka tidak cukup untuk membeli makanan bergizi. Ibu hamil memperoleh asupan makanan yang buruk selama kehamilan. Umumnya mereka hanya mengkonsumsi apa yang mereka miliki yakni umbi-umbian atau singkong. Kondisi Desa Karangpatihan kering, tandus dan terpencil. Akibat dari semua itu, mereka hidup dalam kemiskinan dan rawan mengalami stunting (kondisi kurang gizi kronis).

Dalam penjelasan umum Undang-Undang Nomor 8 Tahun 2016 tentang Penyandang Disabilitas dikemukakan bahwa kandungan Undang-Undang Nomor 4 Tahun 1997 tentang Penyandang Cacat cenderung bersifat belas kasihan (charity based) melalui program jaminan sosial, rehabilitasi sosial, bantuan sosial, dan peningkatan kesejahteraan sosial. Penyandang 


\section{JURNALKU}

Volume 1 No. 4, Desember 2021

Disabilitas desa Karangpatihan yang selama ini mendapat bantuan kambing lokal untuk dikembangkan sebagai pendapatan tahunan, diperkenalkan pemeliharaan kambing perah mendapatkan kesempatan yang sama dengan peternak non disabilitas untuk mendapatkan pendapatan harian dari kambing perah.

Tujuan penelitian ini adalah untuk membuat model bisnis beternak hewan kambing dalam rangka pemberdayaan masyarakat penyandang disabilitas di Desa Karangpatihan. Pemberdayaan masyarakat pra sejahtera dan penyandang disabilitas dengan pendekatan mengelola produk/komoditas untuk menghasilkan pendapatan harian, triwulan atau tahunan telah dilakukan Pemerintah Desa Karangpatihan. Produk yang sudah digulirkan adalah pembuatan keset, batik ciprat, ternak lele dan terakhir kambing. Berkaitan dengan hal-hal tersebut, tulisan ini akan membahas hasil penelitian mengenai penyusunan model bisnis peternakan kambing perah milik rakyat bagi masyarakat disabilitas di Desa Karangpatihan.

\section{KAJIAN PUSTAKA}

Indonesia telah menandatangani CRPD (The Convention of the Human Rights of Persons with Disabilities) atau Konvensi Hak Asasi Difabel tahun 2007, menandatangani konvensi tahun 2011 dalam bentuj Undang-Undang Nomor 19 tahun 2011 (Andayani dan Afandi, 2016). Banyak kegiatan dan penelitian telah dilakukan untuk memberikan masukan bagaimana pemerintah dan masyarakat memberikan pemberdayaan kepada para penyandang disabilitas. Namun dirasakan, para penyandang disabilitas masih belum mendapat kesempatan dan masih belum mampu bangkit dari keterpurukan ekonominya (Muti, 2018, dalam Apsari, Raharjo, 2021). International Day of People with Disabilities (IDPWD) telah mengingatkan agar masyarakat meningkatkan kesadaran keberadaan penyandang disabiltas di berbagai aspek kehidupan baik aspek politik, sosial, ekonomi dan budaya (https://pusdatin.kemkes.go.id).

Surwanti (2016) meneliti faktor suksesnya pemberdayaan ekonomi penyandang disabilitas yaitu motivasi penyandang disabilitas, dukungan keluarga, kesesuaian minat dan kapasitas yang dimiliki dalam pemilihan bidang yang ditempuh, peralatan dan modal, pendampingan pemasaran dan pengembangan produk, jaringan kerja dalam masyarakat, lembaga pendampingan pengembangan karier. Wulandari et.al, (2019), meneliti tentang pelaksanaan program "Fruitable Garden" yang dilaksanakan di Desa Karangpatihan. Hasil penelitiannya menemukan bahwa program tersebut dianggap mampu meningkatkan tingkat konsumsi sayur dan buah bagi masyarakat desa. Namun demikian, kegiatan tentunya masih memerlukan dukungan penuh dari pemerintah dan dinas terkait. Dewi (2016) melakukan penelitian berbagai kegiatan pemberdayaan yang berbasis sumber daya masyarakat di Desa Karangpatihan. Hasil penelitiannya menemukan bahwa pemberdayaan masyarakat berbasis penguatan amat diperlukan.

Jannah, Setianto, \& Muatip,(2021) meneliti dampak pandemi COVID-19 pada peningkatan permintaan susu kambing dan pupuk dari kotoran domba dan kambing. Sebalinya permintaan daging menurun yang menyebabkan permintaan bakalan domba dan kambing menurun. Pandemi COVID-19 turut menaikkan harga konsentrat, sementara peternak kekurangan ampas tahu yang merupakan pakan penguat sumber protein bagi kambing dan domba.

Dalam beternak kambing, terdapat beberapa keuntungan dan kendala yang akan dihadapi oleh para peternak. Keuntungan beternak kambing antara lain modal yang dibutuhkan relatif kecil dibanding beternak sapi, kerbau, atau kuda, pemeliharaan relatif mudah, tidak butuh tempat luas, termasuk skala industri kecil, tidak memerlukan tenaga manusia yang banyak, dapat memperoleh anakan kambing lebih dari satu ekor, semua bagian tubuh kambing bisa dimanfaatkan, dan banyak lagi keuntungan yang lain. Sedangkan kendala-kendalanya kesulitan 


\section{JURNALKU}

Volume 1 No. 4, Desember 2021

mencari pakan natural berupa rumput, kesulitan dalam penggembalaan, kambing memilki bau yang tidak sedap, perlu lokasi kendang yang jauh dari pemukiman.

\section{Model Bisnis Kanvas Peternakan Kambing}

Usaha ternak bagi penduduk pedesaan menjadi sumber protein dan tambahan penghasilan. Usaha ternak di pedesaan dilakukan secara berkelompok. Keuntungan berkelompok antara lain adalah para peternak bisa belajar bersama dan mudah dilakukan penyuluhan oleh pemerintah (Bulan dan Subekti, 2019).

Model bisnis kanvas peternakan kambing perah bagi masyarakat desa Karangpatihan dapat menjadi salah satu upaya meningkatkan pendapatan peternak. Dipercaya bahwa, organisasi dalam hal ini peternak yang berhimpun dalam kelompok tani/ternak dapat tumbuh pesat dengan menciptakan model bisnis yang tepat. Menurut Fathurohman (2016) dalam Fathurohman (2018), business model canvas (BMC) atau disebut juga dengan model bisnis kanvas dianggap berhasil mengubah konsep rumit menjadi sederhana.

Model bisnis kanvas banyak variasinya, Ojasalo (2018) mengembangkan model bisnis kanvas sebagai service logic oriented framework. Model tersebut mencakup prinsip-prinsip dasar dari tiga logika bisnis yang berfokus pada nilai pelanggan kontemporer: logika dominan layanan, logika layanan, dan logika dominan pelanggan. Model yang dikembangkannya, terkenal dengan sebutan Service Logic Business Model Canvas merupakan modifikasi dari model yang dibuat Osterwalder dan Pigneur (2010) dalam Ojasalo (2018).

Dalam penelitian ini, konsep model bisnis kanvas adalah sebagai berikut:

Gambar 1 Konsep Model Bisnis Kanvas

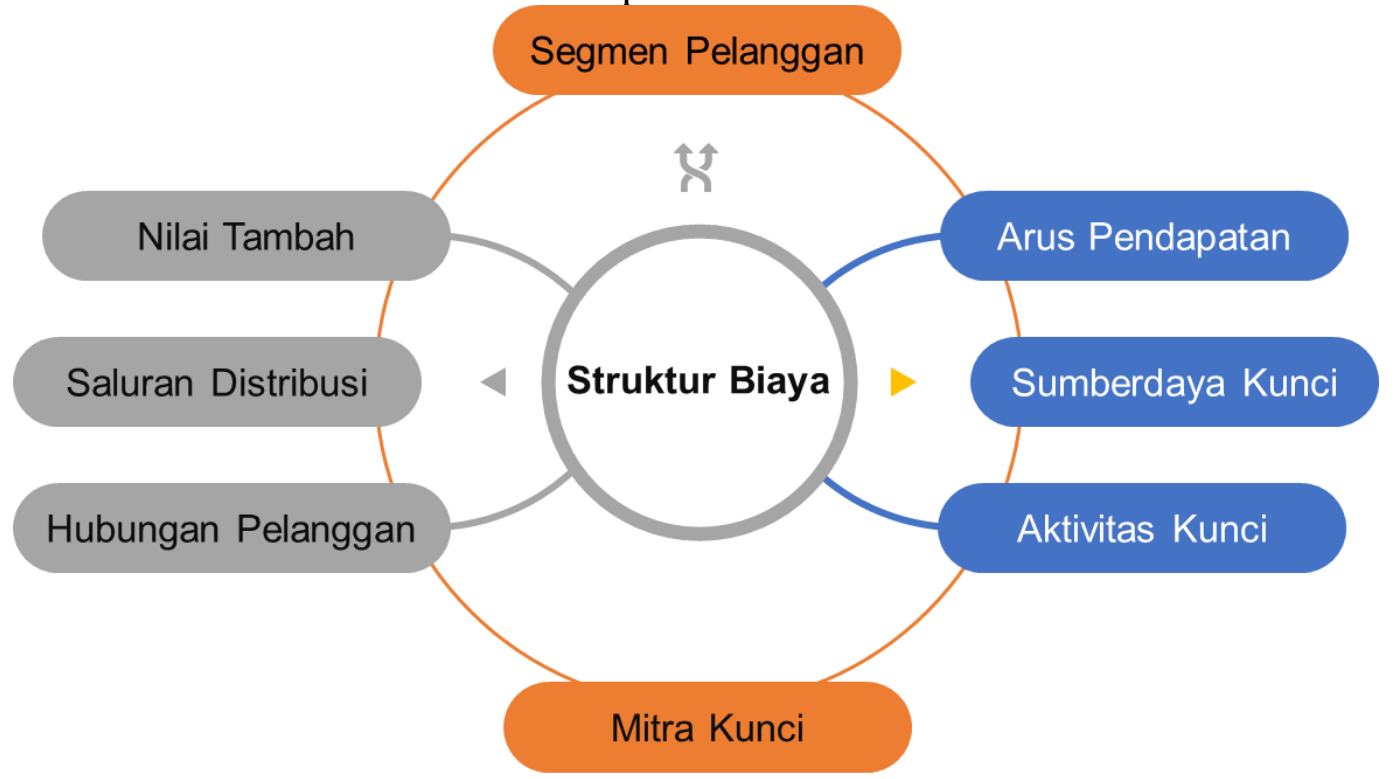

Berdasarkan Gambar 1, canvas business model, dapat tersusun dari 9 segmen penting yang akan kita analisis, di antaranya: Segmen Pelanggan menjelaskan siapa pelanggan kita dan mengapa pelanggan harus membeli produk dan atau layanan dari kita. Di segmen ini kita dapat menyusun info/data terkait pelanggan misalnya jenis kelamin, alamat, usia, kebiasaan, dan lainlain yang berkaitan dengan demografi pelanggan. Segmen Nilai Tambah menjelaskan nilai produk dan layanan apa yang dapat menarik para pelanggan. Apakah produk dan atau layanan kita dapat memuaskan mereka dan bisa menjadi solusi pemenuhan kebutuhan mereka? Di segmen ini kita juga dapat mendefinisikan kegunaan dan manfaat produk dan atau layanan kita. Segmen Saluran Distribusi menjelaskan bagaimana kita mampu memperkenalkan produk dan atau layanan kita. Pada saat memperkenalkan produk dan atau layanan kita, teknologi internet dan social media bisa digunakan. 


\section{JURNALKU}

Volume 1 No. 4, Desember 2021

Segmen Hubungan Pelanggan, yang menjelaskan bagaimana cara memelihara dan menjaga pelangga agar tidak meninggalkan produk dan atau jasa layanan kita. Segmen Pendapatan, yang menjelaskan bagaimana usaha penjualan dari produk dan atau jasa layanan kita dapat menghasilkan pendapatan. Cara memperoleh pendapatan dengan melakukan misalnya sistem penjualan langsung (direct selling), sistem agen, sistem reseller, sistem pembelian dengan diskon/potongan harga, sistem pembelian dengan berutang, dan teknikteknik penjualan lainnya. Sedangkan segmen Sumber Daya Kunci, yang menjelaskan bagaimana sumber daya bisa kita dapatkan dan miliki dalam rangka menghasilkan produk dan atau jasa layanan.

Segmen Mitra Kunci menjelaskan bagaimana rekan bisnis/usaha dapat membantu dan mengembangkan usaha. Bisnis atau usaha memerlukan bantuan dari pebisnis/pengusaha lain, karena bisnis pada dasarnya adalah rantai usaha. Pemilihan partner bisnis/rekan usaha yang cocok akan dapat meningkatkan kemajuan bisnis kita. Segmen Aktivitas Kunci menjelaskan bagaimana suatu proses atau tahapan proses produksi dilakukan. Inti dari segmen ini adalah penyiapan faktor-faktor produksi secara efisien. Terakhir, Segmen Struktur Biaya menjelaskan bagaimana sebuah usaha harus dibiayai. Dalam melakukan usaha terdapat apa yang dinamakan biaya tetap (yang harus dibayar meskipun tidak sedang berproduksi, seperti gaji karyawan, gaji keamanan, dan lain-lain) dan biaya tidak tetap (umumnya dikaitkan dengan saat melakukan proses produksi seperti pembelian bahan baku).

\section{METODE}

Penelitian ini adalah penelitian kualitatif studi kasus ini menggunakan pendekatan kualitatif dimaksudkan untuk mengeksplorasi kehidupan nyata, sistem terbatas kontemporer (kasus), atau beragam sistem terbatas. Eksplorasi dilakukan melalui pengumpulan data detil dan mendalam yang melibatkan beragam sumber informasi atau sumber informasi majemuk seperti pengamatan, wawancara, bahan audiovisual, dokumen dan berbagai laporan. Satuan analisis dalam studi kasus bisa berupa kasus majemuk (studi multi situs) atau kasus tunggal (Creswell, 2013).

Dalam peroses pengumpulan data dan infromasi untuk bahan penelitian, kami juga menggunakan metode participatory rural appraisal (PRA). Metode PRA memungkinkan masyarakat desa saling berbagi, menambah dan menganalisis pengetahuan tentang kondisi kehidupannya untuk membuat perencanaan dan tindakan (Lestari, et.al, 2020, Hudayana, et. Al, 2019).

Dalam pelaksanaannya, segala informasi dan data yang kami dapatkan sebagai bahan penelitian lebih banyak dilakukan dengan cara berdiskusi. Anggota masyarakat desa yang cukup aktif dalam berdiskusi adalah Sdr. Arifin dan Sdr. Paiman. Dalam metode PRA, kesepakatan bersama menjadi pegangan bagi peneliti. Sehingga, dalam penelitian ini kami tidak menyebutkan setiap nama informan dalam pembahasan permasalahannya, melainkan dengan penyebutan menurut masyarakat desa, kesepakatan Bersama, dan sebutan lainnya yang setara.

\section{HASIL DAN PEMBAHASAN}

Studi kualitatif dengan menggunakan pendekatan PRA merupakan model yang cocok untuk memperdalam penyelidikan (inquiry). Fakta empiris yang digali dilapangan berupa proses pemberdayaan penyandang disabilitas di pedesaan. Studi seperti ini memiliki salah satu ciri yaitu adanya bounded system (saling terkait), yang ditandai adanya batasan lokasi, waktu kejadian/peristiwa, proses aktivitas termasuk suatu kebijakan.

Desa Karangpatihan merupakan salah satu desa dengan penyandang disabilitas cukup banyak yang telah menjalankan berbagai program pemberdayaan penyandang disabilitas. Akan tetapi, diketahui bahwa keterlibatan pemerintah daerah masih dirasakan sangat minim. 


\section{JURNALKU}

Volume 1 No. 4, Desember 2021

Beberapa diskusi secara intens (Gambar 2) dengan para peternak kambing telah kami lakukan, khususnya di desa sekitaran Ponorogo Jawa Timur dan Kota Tangerang Selatan, Banten. Diskusi-diskusi tersebut sangat diperlukan dalam melakukan penelitian untuk membuatkan model bisnis kanvas di Desa Karangpatihan.

Gambar 2 Foto Saat Diskusi dengan Peternak Kambing
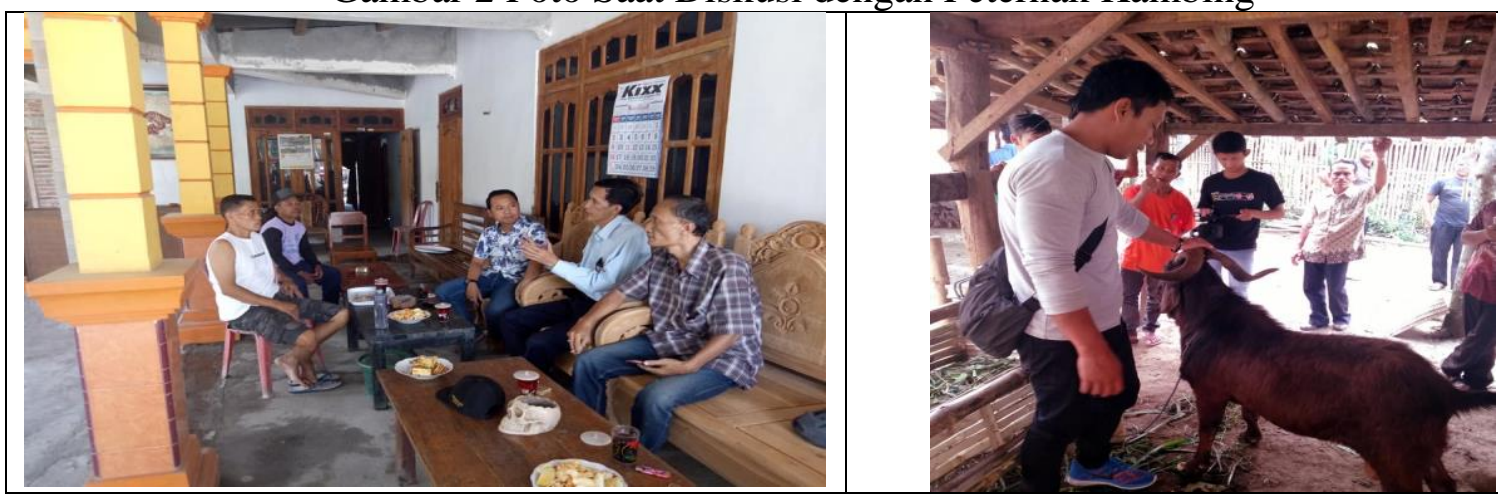

Hasil pendataan kami terhadap kepemilikan hewan ternak di Desa Karangpatihan sebagaimana tersaji dalam Tabel 1. Dalam tabel tersebut terdapat 20 peternak yang memiliki hewan ternak kambing. Rata-rata jumlah kepemilikan hewan ternak mereka sangat sedikit. Hanya Saudara Paiman yang memiliki jumlah hewan ternak kambing mencapai 26 ekor, termasuk anak kambing (cempe). Dari Tabel 1 nampak bahwa kepemilikan hewa ternak di Desa Karangpatihan ada dalam skala sangat kecil.

Tabel 1 Mitra Peternak Kambing Desa Karangpatihan - Ponorogo

\begin{tabular}{|c|l|c|c|c|c|c|c|c|c|}
\hline \multirow{2}{*}{ No. } & Mitra & \multicolumn{4}{|c|}{ Indukan } & \multicolumn{3}{c|}{ Cempe } & \multirow{2}{*}{ Total } \\
\cline { 3 - 9 } & Peternak & Betina & Jantan & Mati & Sisa & Jantan & Betina & Jumlah & \\
\hline 1 & Paiman & $\mathbf{8}$ & $\mathbf{4}$ & $\mathbf{2}$ & $\mathbf{1 0}$ & $\mathbf{1 0}$ & $\mathbf{6}$ & $\mathbf{1 6}$ & $\mathbf{2 6}$ \\
\hline 2 & Poniran & $\mathbf{2}$ & & $\mathbf{1}$ & $\mathbf{1}$ & & & $\mathbf{0}$ & $\mathbf{0}$ \\
\hline 3 & Bejan & $\mathbf{3}$ & & & $\mathbf{3}$ & & & $\mathbf{0}$ & $\mathbf{3}$ \\
\hline 4 & Sarno & $\mathbf{2}$ & & & $\mathbf{2}$ & $\mathbf{2}$ & & $\mathbf{2}$ & $\mathbf{4}$ \\
\hline 5 & Tukimun & $\mathbf{3}$ & & $\mathbf{1}$ & $\mathbf{2}$ & $\mathbf{4}$ & & $\mathbf{4}$ & $\mathbf{6}$ \\
\hline 6 & Larijo & $\mathbf{1}$ & & & $\mathbf{1}$ & & & $\mathbf{0}$ & $\mathbf{1}$ \\
\hline 7 & Arifin & $\mathbf{2}$ & & & $\mathbf{2}$ & & & $\mathbf{0}$ & $\mathbf{2}$ \\
\hline 8 & Daman & $\mathbf{2}$ & & & $\mathbf{2}$ & & & $\mathbf{0}$ & $\mathbf{2}$ \\
\hline 9 & Rukun & $\mathbf{1}$ & & & $\mathbf{1}$ & $\mathbf{2}$ & $\mathbf{2}$ & $\mathbf{4}$ & $\mathbf{5}$ \\
\hline 10 & Laman & $\mathbf{1}$ & & & $\mathbf{1}$ & $\mathbf{1}$ & & $\mathbf{1}$ & $\mathbf{2}$ \\
\hline 11 & Misni & $\mathbf{2}$ & & & $\mathbf{2}$ & & & $\mathbf{0}$ & $\mathbf{2}$ \\
\hline 12 & Didik & $\mathbf{1}$ & & & $\mathbf{1}$ & $\mathbf{1}$ & & $\mathbf{1}$ & $\mathbf{2}$ \\
\hline 13 & Indro & $\mathbf{2}$ & & $\mathbf{1}$ & $\mathbf{1}$ & & & $\mathbf{0}$ & $\mathbf{1}$ \\
\hline 14 & Suyitno & $\mathbf{1}$ & $\mathbf{1}$ & & $\mathbf{2}$ & & & $\mathbf{0}$ & $\mathbf{2}$ \\
\hline 15 & Paikun & $\mathbf{1}$ & & & $\mathbf{1}$ & $\mathbf{1}$ & $\mathbf{1}$ & $\mathbf{2}$ & $\mathbf{3}$ \\
\hline & Purwo & & & & & & & & \\
16 & Utomo & $\mathbf{2}$ & & & $\mathbf{2}$ & & & $\mathbf{0}$ & $\mathbf{2}$ \\
\hline 17 & Jakfar & $\mathbf{7}$ & & & $\mathbf{7}$ & & & $\mathbf{0}$ & $\mathbf{7}$ \\
\hline 18 & Warsito & $\mathbf{2}$ & & & $\mathbf{2}$ & & & $\mathbf{0}$ & $\mathbf{2}$ \\
\hline 19 & Pairin & $\mathbf{1}$ & & & $\mathbf{1}$ & & & $\mathbf{0}$ & $\mathbf{1}$ \\
\hline 20 & Yanto & $\mathbf{2}$ & & & $\mathbf{2}$ & & & $\mathbf{0}$ & $\mathbf{2}$ \\
\hline \multicolumn{1}{|c|}{ JUMLAH } & $\mathbf{4 6}$ & $\mathbf{5}$ & $\mathbf{5}$ & $\mathbf{4 6}$ & $\mathbf{2 1}$ & $\mathbf{9}$ & $\mathbf{3 0}$ & $\mathbf{7 5}$ \\
\hline
\end{tabular}

Hewan-hewan ternak kambing mereka pelihara di kandang-kandang yang belum memenuhi syarat. Kandang kambing masih beralaskan tanah tanpa penghalang. Sehingga, 


\section{JURNALKU}

Volume 1 No. 4, Desember 2021

banyak kambing yang seperti mengalami sakit dan kedinginan karena kaki dan tubuhnya bersentuhan langsung dengan tanah yang kotor dari kotoran mereka.

Cara penggembalaan kambing juga dirasakan masih kurang tepat. Kambing lebih sering berada di dalam kendang dibanding di gembalakan di alam terbuka. Sebagaimana sudah disampaikan di atas, kondisi daerah Desa Karangpatihan tergolong tandus, kering, dan terpencil. Penggembalaan hewan di alam terbuka, oleh penduduk dianggap tidak efektif. Kambing jika dilepas di alam terbuka tidak dapat memperoleh makanan natural yang mencukupi.

Para pemilik kambing memang tidak semuanya menyandang disabilitas. Namun, sebagai industri, peternakan kambing di Desa Karangpatihan diharapkan dapat berkembang. Sehingga, industry ini nantinya akan membantu membuka lapangan kerja bagi para penyandang disabilitas. Oleh karena itu, banyak usulan dari pemilik ternak kambing agar dapat memperoleh pengetahuan dan permodalan yang memadai mengenai pengelolaan peternakan kambing. Meskipun, Desa Karangpatihan tergolong bukan desa yang potensial untuk melakukan bisnis hewan ternak.

Dalam upaya membantu masyarakat Desa Karangpatihan, penulis mencoba membuatkan model bisnis kanvas sebagaimana Gambar 2.

Gambar 2 Model Bisnis Kanvas Peternakan Kambing Perah Desa Karangpatihan

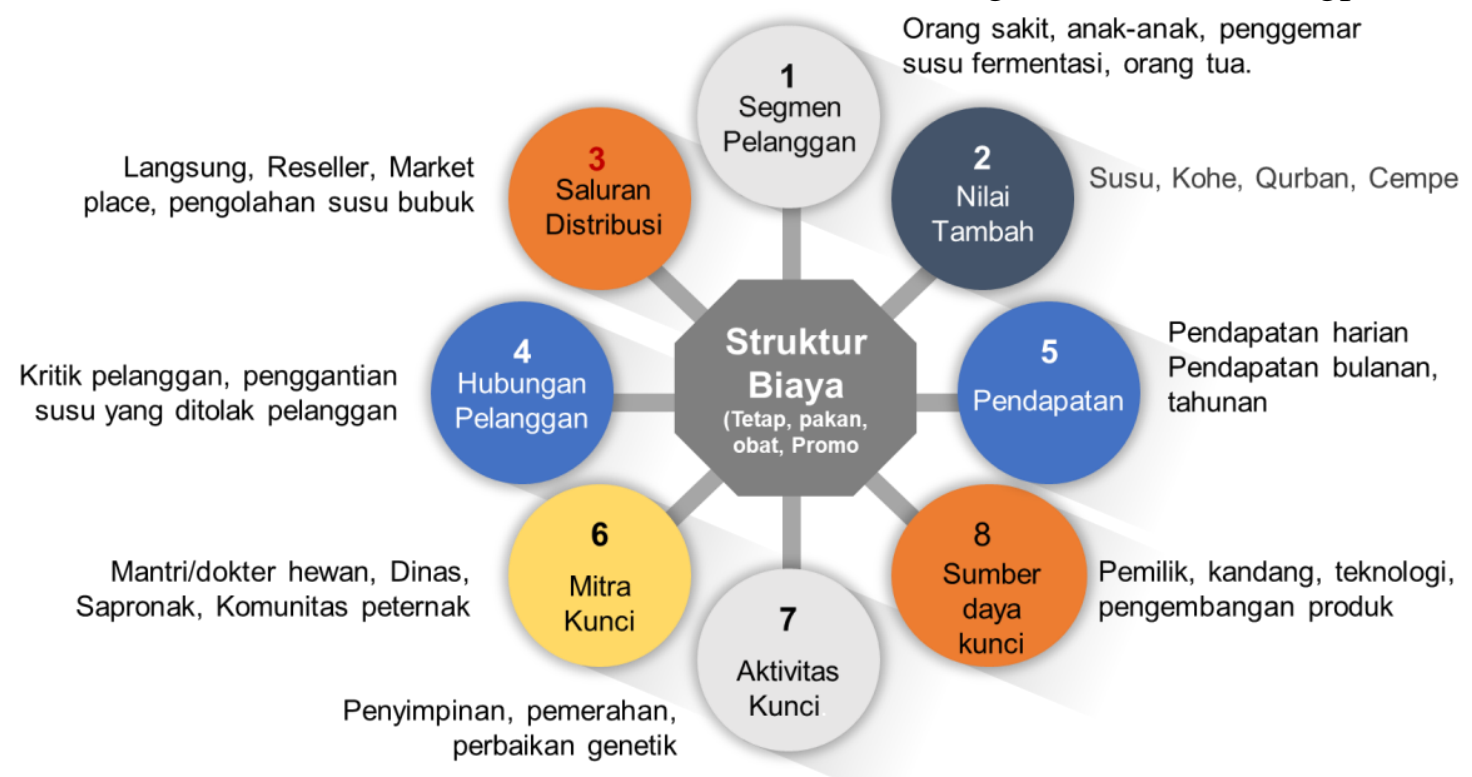

Model bisnis sebagaimana Gambar 2 dapat kami jelaskan sebagai berikut:

Segmen Pelanggan, terdiri dari orang sakit, anak-anak, penggemar susu fermentasi, dan orang tua-usia lanjut.

Nilai susu kambing didasarkan pada segmentasi pasar yang telah ditentukan masyarakat. Sasaran utama konsumen susu kambing dalam model bisnis ini adalah adalah orang yang paru-paru atau orang tua yang membutuhkan kalsium dalam memperkuat tulang, Susu kambing bisa menggantikan susu formula untuk manula yang selama ini beredar. Komposisi nutrisi yang terkandung dalam susu kambing yang menyerupai ASI bisa dilanjutkan minum susu kambing ketika balita sudah lepas dari ASI di usia 1 tahun ke atas. Dalam konteks ini peternak kambing perah desa Kararangpatihan sudah memulai pemberian susu kambing untuk anak usia 1 tahun ke atas di pos Yandu desa. Dalam hal ini susu kambing sebagai alternatif pangan yang dihasilkan dari kandang peternak untuk menjalankan program pengurangan stunting yang digulirkan peerintah. 


\section{JURNALKU}

Volume 1 No. 4, Desember 2021

\section{Segmen Nilai Tambah, terdiri dari susu, kohe (kotoran hewan), qurban, cempe.}

Penentuan segmen nilai ternak kambing perah merupakan upaya peternak dalam rangka menarik konsumen dan memperluas pasar susu kambing. Segmen nilai ini melihat manfaat produk kambing perah yang ditawarkan kepada konsumen agar produk kambing perah mampu memenuhi kebutuhan konsumen dan memberikan solusi permasalahan konsumen. Persepsi umum di masayarakat yang telah terbentuk dan terbukti secara medis menempatkan susu kambing sebagai obat terutama untuk penyakit yang berhubungan dengan paru-paru dan kesehatan lambung. Dalam pengembangan lebih lanjut, dengan teknologi sederhana, produk susu kambing bisa diolah untuk sabun mandi bagi penduduk desa atau dijual melalui marketplace. Produk olahan lain dari susu kambing adalah susu fermentasi baik untuk yogurt maupun untuk kefir untuk segmen pelanggan penggemar susu fermentasi. Kotoran kambing dari kencing maupun yang dalam bentuk butiran dalam diolah menjadi kompos dan dikemas dalam karung $10 \mathrm{~kg}$ untuk dijual sebagai pupuk. Bagi masyarakat pedesaan, keberadaan kotoran kambing menjadi solusi alternatif ketika terjadi kelangkaan pupuk kimia yang menjadi andalan petani. Nilai tambah lain dari kambing perah adalah cempe betinanya lebih tinggi harganya dibanding cempe jantan karena nantinya akan menghasilkan produk susu. Cempe jantan kambing perah nilai tambahnya dari tanduk yang besar sehingga memberi tampilan lebih untuk dijual pada saat Idhul Adha.

Segmen Saluran Distribusi, terdiri dari langsung, reseller, marketplace, pengolah susu bubuk.

Posisi kendang kambing perah yang berada di pedesaan membuat para peternak berpikir keras agar produk kambing perah bisa menjangkau pelanggan. Produk sampingan berupa kohe (kotoran hewan) bisa langsung dijual ke petani setempat, sementara produk susu dan cempe kambing perah sebagai produk khusu memerlukan teknologi internet dan social media untuk menjangkau konsumen khusus.Saluran pelanggan menggambarkan cara peternak mengenalkan segmen nilai kepada konsumen melalui distribusi dan saluran penjualan untuk meningkatkan kepedulian terhadap konsumen akan produk dari kambing perah. Saluran konsumen utama yang digunakan selama ini masih bersifat pembelian langsung ke kendang peternak. Perbembangan marketplace yang pesat dan munculnya moda pengantaran Gojek dan Grab memungkinkan peternak untuk memasarkan produk susu ke market place yang hal ini terbukti pada saat puncak pandemi COVID-19 susu kambing banyak dijual dan dicari lewat markert place. Susu kambing cair yang yang tidak tahan lama mulai dilakukan pengolahan berupa susu bubuk seperti yang dilakukan peternak dan pengusaha pengolahan susu kambing di kecamatan Girikerto kabupaten Sleman-Yogyakarta.

Segmen Hubungan Pelanggan, terdiri dari kritik pelanggan, penggantian susu yang ditolak pelanggan (customer care).

Sifat susu kambing yang dijual dalam bentuk cair yang penanganannya tidak benar bisa mudah rusak dan hal ini rawan pengaduan dari konsumen. Peternak yang jeli untuk menjaga loyalitas pelanggan akan mengganti susu kambing cair yang rusak dalam penanganan di peternak. Demikian pula susu kambing cair yang bau kambing menyengat membuat pelanggan tifdak puas, Dalam hal bau susu kambing yang menyengat peternak akan memperbaiki penanganannya dengan tidak memerah kambing di kendang tapi di tempat khusus. Informasi bau susu kambing yang menyengat berguna bagi peternak untuk meningkatkan kualitas susunya.

Segmen Pendapatan, terdiri dari pendapatan harian, mingguan, bulanan, tahunan.

Para penyandang disabilitas di desa Karangpatihan selama ini diberdayakan dengan kegiatan pembuatan keset dari kain perca dan kerajinan batik ciprat untuk memperoleh pendapatan harian dan mingguan dari upah menyelesaikan keset dan batik ciprat. Upah diberikan kepada penyandang disabilitas terlatih setelah seminggu menyelesaikan pekerjaan. 


\section{JURNALKU}

Volume 1 No. 4, Desember 2021

Untuk pendapatan bulanan dan triwulanan mereka diperkenalkan dengan ternak ayam dan ternak lele serta kambing lokal. Searagan virus flu burung menurunkan populasi ternak ayam yang dimiliki penyandang disabilitas dan harga pakan lele yang melambung tinggi tidak sebanding dengan hasil atau keuntungan yang dicapai. Kambing lokal atau kambing pedaging yang dipelihara penyandang disabilitas hanya menghasilkan pendapatan tahunan ketika cempe yang dilahirkan setahun kemudian bisa dijual pada hara Raya Idhul Qurban yang harganya lebih tinggi. Upaya untuk menciptakan pendapatan harian, mingguan dan bulanan akhirnya melirik kambing perah sebagai alternatif. Karena kambing perah memerlukan perawatan khusus terutama penanganan susu kambing yang tidak bisa ditangani penyandang disabilitas, maka uji coba pemeliharaan kambing perah di Desa Karangpatihan dimulai dari peternak kambing lokal yang memiliki induk kambing betina maupun dara kambing betina untuk dikawinkan dengan pejantan kambing agar menghasilkan anakan yang nantinya produksi susu lebih banyak. Bagaimana usaha penjualan dari produk kambing perah dapat menghasilkan pendapatan? Cara memperoleh pendapatan bisa dilakukan dengan misalnya sistem penjualan langsung (direct selling), sistem agen, sistem reseller, sistem pembelian dengan diskon/potongan harga, sistem pembelian dengan berutang, dan teknik-teknik penjualan lainnya. Pendapatan yang diperoleh dari model bisnis kambing perah adalah penjualan susu harian yang diperah pagi dan sore hari. Ssusu kambing cair langsung dibekukan di freezer dan dismpan falam kulkas sehingga bisa melayani konsumen harian. Pendapatan peternak kambing perah secara bulanan bisa dihasilkan dari kotoran hewan berupa kencing dan butiran yang dikumpulkan dan setelah menumpuk sebulan bisa diolah menjadi kompos untuk pendapatan bulanan. Sedangkan pendapatan tahunan dari peternak kambing perah adalah penjualan kambing jantan yang merupakan panen tahun pada hari raya Idhul Kurban.

\section{Segmen Mitra Kunci, terdiri dari mantri/dokter hewan, dinas, saprontak, komunitas peternak.}

Sumber daya kunci dalam model bisnis kambing perah mencakup susu kambing dan produk turunannya, sumber daya manusia berupa karyawan dan mantri/dokter hewan yang sangat dibutuhkan ketika peternak menghadapi kambing yang sakit. Mantri/dokter hewan diperlukan oleh peternak kambing perah diperlukan karena trnasformasi pemeliharaan dari kambing biasa/kambing pedaging ke kambing perah perlu pengetahuan yang lebih kompleks. Para peternak terbiasa memelihara kambing lokal yang tahan parasit meskipun kandangnya beralaskan tanah. Kambing perah membutuhkan kendang panggung yang bersih untuk menghindari cemaran pada produk susu dan penyekit yang menyerang kambing perah akibat kendang yang kumuh. Transformasi dari kendang tanah ke kandng panggung membutuhkan waktu dan selama proses transformasi, peran mantri/dokter hewan sangant penting dalam meribah perilaku peternak untuk memperhatikan aspek kesehatan kendang. Kemitraan dengan peternak lain juga membantu transformasi pengetahuan peternak melalui partisipasi mereka dalam grup Whatsapp tenpat para anggotanya saling berbagi ilmu dan pengalaman tentang pengelolaan kambing perah, penanganan penyakit dan pemasaran produk kambing perah. Mitra kunci lain terkait upaya meningkatkan pengetahuan dan teknologi pengolahan dan pengembangan susu kambing dengan mengirimkan salah satu anggota peternak kambing untuk mengikuti pelatihan di Peternakan Bhumi Nararya Farm yang memiliki 700 ekor kambing perah dan telah berhasil melakukan pengoalahan produk susu kambing menjadi keju dan turunannya agar pengetahuan masyarakat desa tentang ternak kambing modern lebih terbuka. Mitra peternak dalam penjualan produk kambing perah yaitu para pedagang kambing dan reseller produk susu kambing dan turunannya.

Segmen Aktivitas Kunci, terdiri dari penyimpanan, pemerahan, perbaikan genetik.

Aktivitas produksi susu kambing perah yang paling krusial terletajk pada proses atau tahapan proses produksi setelah susu kambing diperah karena susu kambing cair tidak bisa 


\section{JURNALKU}

Volume 1 No. 4, Desember 2021

tahan lama. Inti dari segmen ini adalah penyiapan faktor-faktor produksi yang penting dan efisien karena setelah diperah bila tidak ditangani secara benar akan merusak susu dan berakibat fatal berupa penolakan konsumen. Segera setelah susu kambing diperah langsung dimasukkan dalam freezer agar segera membeku secara cepat. Setelah membeku kemudian susu kambing cair dipindahkan ke kulkas untuk mempertahankan titik bekunya sementara freezer segera dipergunakan untuk secara cepat membekukan susu kambing yang baru diperah. Apabila terlalu lama dalam proses pembekuan, susu kambing beku yang diterima konsumen dan ketika dicairkan untuk diminum akan menimbulkan gumpalan-gumpalan atau susu yang pecah dan hal initidak disukai konsumen. Aktivitas kunci lain. yang dilakukan dalam kanvas model bnis kambing perah yaitu merencanakan pengolahan dan penanganan produk susu kambing secara tepat, penyimpanan dan penanganan paska perah, pengembangan dan pemeliharaan genetik unggul kambing perah, menghindari kawin sedarah antar kambing perah, penjualan dan promosi. Para peternak kambing perah di Karangpatihan memanfaatkan momentum kejuaraan sepakbola bola se-Karesidenan Madiun untuk melakukan promosi susu produk Karangpatihan. Segmen Sumber Daya Kunci, terdiri dari pengetahuan pemilik, kualitas kandang, teknologi, pengembangan produk.

Dalam rangka menghasilkan produk kambing perah dan atau jasa layanannya, terdapat pihak yang terlibat langsung dalam pengembangan model bisnis usaha produk kambing perah antara lain peternak kambing perah itu sendiri, pengolah susu bubuk, peneliti, dan pemerintah. Peternak kambing perah yang memiliki modal, mengembangkan model reseller di kota dengan meminjamkan kulkas untuk menampung susu dari peternak agar konsumen dari kota lebih mudah menjangkau pembelian. Peneliti dan pemulia kambing perah disini berperan sebagai agen yang membantu dalam pengembangan genetik kambing perah menghasilkan susu tinggi. Pemerintah memiliki perannan penting dalam mendukung pengembangan dan penyediaan kambing perah yang berkualitas melalui Kementerian Pertanian atau Dinas Pertanian. Sebagai contoh, Balai Besar Pembibitan Ternak Unggul dan Hijauan Pakan Ternak Baturraden di Cilacap selama ini berfungsi sebagai instansi pemerintah di bawah Kementerian Pertanian yang menyediakan pejantan unggul kambing perah jenis Saanen untuk dikawinkan dengan kambing lokal dalam meningkatkan kuantitas susu yang dihasilkan keturunannya.

Segmen Struktur Biaya, terdiri dari biaya tetap, biaya pakan, biaya obat, biaya promo.

Berbeda dengan beternak kambing lokal/pedaging, beternak kambing perah membutuhkan struktur biaya yang berbeda. Terdapat apa yang dinamakan biaya tetap dibutuhkan dalam pengembangan model bisnis ini yaitu biaya teknologi pembuatan kendang panggung yang merupakan modifikasi dari kendang tanah agar suasana kendang bersih untuk mempertankan dan menjaga kambing perah dari serangan penyakit. Dalam hal ini peternak desa Karangpatihan memanfaatkan kearifan lokal untuk menjaga Kesehatan dengan menyemprot kendang menggunakan desinfektan yang dibuat dari 1 bagian cairan Bayclin dicampur dengan 9 bagian air. Biaya tidak tetap umumnya dikaitkan dengan saat melakukan proses produksi seperti pengadaan bahan pakan hijauan ternak dengan memanfaatkan limbah pohon jagung yang gratis didapatkan peternak dari petani jagung selanjutnya dipotong menggunakan mesin pemotong dilanjutkan penyimpanan dalam drum plastic kedap udara yang hasilnya berupa silase yang tahan 2 tahun penympanan untuk menghadapi musim kemarau ketika bahan pakan susah didapat. Dengan demikian, drum dan mesin pemotong hijauan pakan ternak merupakan bagian dari biaya tetap. Baya promosi penjualan susu kambing di marketplace masih dalam rancangan sementara biaya teknologi berupa biaya yang dikeluarkan peternak untuk mendapatkan pejantan perah lain yang berkualitas untuk dikawinkan dengan induk betina local supaya menghasilkan cempe betina berkualitas perah agar tidak terjadi inbreeding (perkawinan sedarah). Riset pengembangan produk susu kambing agar dapat menjaga kualitasnya sesuai dengan kualitas produk susu kambing yang difermentasi secara alami merupakan rencana 


\section{JURNALKU}

Volume 1 No. 4, Desember 2021

selanjutnya, sedangkan biaya promosi yang telah dikeluarkan para peternak merupakan biaya memperkenalkan susu kambing pada masyarakat luas secara online maupun secara langsung kepada konsumen melalu sampel produk untuk meyakinkan kepada masyarakat bahwa susu kambing itu murni, berkhasiat dan harum. Mereka terlibat dalam mensponsori kejuaran sepakbola se Karesidenan Madiun yang diselenggarakan di kecamatan dengan imbalan pemasangan spanduk promosi susu produk Karangpatihan.

Model bisnis kanvas yang telah berhasil dibuat berdasarkan diskusi secara bersama dengan peternak kambing di Desa Karangpatihan mungkin masih belum sempurna. Model bisnis tersebut masih perlu diujicobakan dalam waktu jangka panjang, karena jumlah peternakan mereka juga masih sedikit. Evaluasi secara terus menerus guna penyempurnaan model bisnis tersebut akan sangat dipengaruhi dengan kenaikan volume bisnis mereka.

Sebagaimana bisnis pada umumnya, problem permodalan dan pemasaran menjadi masalah yang dominan dalam setiap diskusi. Di satu sisi, kondisi daerah mereka memerlukan rekayasa tekhnologi agar dapat mengakomodir usaha peternakan. Rekayasa kandang kambing misalnya, perlu dilakukan agar kambing-kambing dapat menempati kandang yang bersih dan memilki lantai. Selain itu, problem penyediaan pakan kambing juga memerlukan sentuhan tekhnologi agar dapat menyediakan pakan kambing buatan yang bergizi, harga yang terjangkau, dan berkesinambungan. Selain itu, pengelolaan produk-produk yang dihasilkan dari peternakan seperti susu, kohe (kotoran hewan kambing), daging, dan lainnya juga memerlukan teknik pengolahan yang tidak sederhana.

\section{PENUTUP}

Desa Karangpatihan adalah sebuah desa Kecamatan Balong, Ponorogo Jawa Timur. Desa Karangpatihan merupakan salah satu desa dengan penyandang disabilitas cukup banyak. Masyarakat Dea Karangpatihan memiliki keinginan untuk melakukan ternak kambing perah. Dalam menjalankan bisnis ternak kambing perah, masyarakat desa Karangpatihan mengalami beberapa kendala. Kendala-kendala tersebut berupa misalnya pengetahuan sumber daya peternak yang masih tradisional, curah hujan yang relatif sedikit sehingga menyebabkan kekeringan, dan menyulitkan warga untuk mendapatkan pakan ternak natural. Dengan menggunakan metode PRA, masyarakat peternak di Desa Karangpatihan mengembangkan Model Bisnis Kanvas. Dalam perkembangannya, model bisnis tersebut akan dilaksanakan dan secara berkala akan dievaluasi tingkat efektifitasnya sesuai kebutuhan.

\section{DAFTAR PUSTAKA}

Aprianto, K.T., Rasyad, A. and Zulkarnain, Z., (2019). Pendampingan Partisipatori dalam Meningkatkan Kemandirian Masyarakat Tunagrahita. Jurnal Pendidikan: Teori, Penelitian, dan Pengembangan, 4(6), pp.795-802

Apsari, N.C. and Raharjo, S.T., (2021). Orang dengan Disabilitas: Situasi Tantangan dan Layanan di Indonesia. Buletin Penelitian Sistem Kesehatan, 24(3), pp.159-169. DOI: https://doi.org/10.22435/hsr.v24i3.3069

Badan Pusat Statistik Kabupaten Ponorogo, (2018). Kecamatan Balong Dalam Angka 2018.

Bulan, D.S. and Subekti, S., 2019. Proses Pembelajaran Sosial Perkandangan pada Peternak Kambing. UNEJ e-Proceeding

Creswell, J.W. (2013). Qualitative Inquiry and Research Design: Choosing Among Five Approaches. Third Edition. Translated by Saifuddin Zuhri Qudsy. Student Library. Yogyakarta.Klingner and Boardman, 2011

Dewi, D.S.K., (2016). Model Pemberdayaan Masyarakat Tunagrahita di Kampung Idiot Kabupaten Ponorogo. Otoritas: Jurnal Ilmu Pemerintahan, 6(1), pp.21-27) 


\section{JURNALKU}

Volume 1 No. 4, Desember 2021

Fathurohman, F., (2018). Model Bisnis Kawasan Peternakan Kabupaten Subang. Jurnal ilmiah ilmu dan Teknologi Rekayasa, 1(1), pp.36-45

Hudayana, B., made Kutanegara, P., Setiadi, S., Indiyanto, A., Fauzanafi, Z., Nugraheni, M. D. F., \& Yusuf, M. (2019). Participatory Rural Appraisal (PRA) untuk Pengembangan Desa Wisata di Pedukuhan Pucung, Desa Wukirsari, Bantul. Bakti Budaya: Jurnal Pengabdian kepada Masyarakat, 2(2), 3-1

Jannah, Z., Setianto, N., \& Muatip, K. (2021). Analisis Dampak Pandemi Covid-19 Terhadap Usaha Ternak Domba Kambing (Studi Kasus Peternak Hpdki Kabupaten Banyumas). Prosiding Seminar Teknologi Agribisnis Peternakan (Stap) Fakultas Peternakan Universitas Jenderal Soedirman,8, 729-734. Retrieved from http://jnp.fapet.unsoed.ac.id/index.php/psv/ article/ view/1215

Lestari, M. A., Santoso, M. B., \& Mulyana, N. (2020). Penerapan Teknik Participatory Rural Appraisal (Pra) Dalam Menangani Permasalahan Sampah. Jurnal Penelitian dan Pengabdian Kepada Masyarakat (JPPM), 1(1), 55-61. DOI : https://doi.org/10.24198/jppm.v1i1.30953

Ojasalo, J. and Ojasalo, K. (2018), "Service Logic Business Model Canvas", Journal of Research in Marketing and Entrepreneurship, Vol. 20 No. 1, pp. 70-98. https://doi.org/10.1108/JRME-06-2016-0015

Suwanti, A. (2014). Jurnal Manajemen Bisnis. Volume 5, Nomor 1, 2014.

Triono, B. (2018). Kebijakan Pemberdayaan Masyarakat Difabel Idiot di Desa Karangpatihan Kecamatan Balong Kabupaten Ponorogo Jawa Timur. JI@ P, 5(1),

Wulandari, R., Anjasari, H., Wulandari, N.D., Jayanti, M.N. and Gunarhadi, G. (2019). Pemberdayaan Warga Keterbelakangan Mental di Desa Karangpatihan Ponorogo melalui Frutable Greden. Jurnal Pemberdayaan Masyarakat Universitas Al Azhar Indonesia, 1(2), pp.78-83., diakses 29 November 2021

https://eprints.umm.ac.id/44293/4/jiptummpp-gdl-bambangsun-51386-4-babiii.pdf, diakses 29 November 2021

https://pusdatin.kemkes.go.id/resources/download/pusdatin/infodatin/infodatin-disabilitas.pdf, diakses 29 November 2021

https://tutorialbudidaya.blogspot.com/2014/08/keuntungan-dan-kendala-beternakkambing.html, diakses 29 November 2021

https://www.ekrut.com/media/business-model-canvas, diakses 29 November 2021 